\title{
Pengaruh Komposisi Campuran Fisik Crospovidone-Sodium Starch Glycolate (1:1, 1:2, dan 1:3) terhadap Karakteristik Fisikokimia Sediaan Tablet Orodispersible Atenolol
}

\author{
Karina Citra Rani, Nani Parfati dan Putu Egik Prasetya \\ Departemen Farmasetika, Fakultas Farmasi Universitas Surabaya, Surabaya
}

Korespondensi: Karina Citra Rani

Email: karinacitrarani@staff.ubaya.ac.id

\begin{abstract}
ABSTRAK: Penggunaan tablet konvensional atenolol menimbulkan masalah dalam hal kepatuhan minum obat pada pasien geriatri. Hal ini disebabkan terjadinya perubahan fisiologis pada pasien geriartri seperti susah menelan dan tremor. Pengembangan atenolol dalam bentuk sediaan tablet orodispersible dapat mempercepat waktu hancur tablet di dalam mulut, sehingga awal proses disolusi menjadi lebih cepat. Pemilihan jenis dan komposisi disintegran yang optimal merupakan hal penting dalam formulasi sediaan tablet orodispersible. Kombinasi crospovidone dan sodium starch glycolate sebagai disintegran dalam formulasi sediaan tablet orodispersible dapat menggabungkan mekanisme aksi wicking dan swelling, sehingga mempercepat waktu disintegrasi tablet. Tujuan penelitian ini adalah mendapatkan pengaruh komposisi campuran fisik superdisintegran (crospovidonesodium starch glycolate) dengan perbandingan 1:1, 1:2, dan 1:3 terhadap karakteristik fisikokimia tablet orodispersible atenolol yang dibuat dengan metode cetak langsung. Hasil evaluasi menunjukkan bahwa tablet orodispersible atenolol dengan perbandingan komposisi campuran fisik superdisintegran (crospovidone dan sodium starch glycolate) 1:1, 1:2, dan 1:3 yang dihasilkan memenuhi persyaratan mutu. Tablet orodispersible atenolol dengan perbandingan campuran fisik superdisintegran (crospovidone-sodium starch glycolate) 1:1 menghasilkan disolusi atenolol yang paling baik dibandingkan formula yang lain ditinjau dari parameter $\% \mathrm{Q}(96,92 \pm 0,01) \%, \mathrm{~T}_{85 \%}(1,76 \pm 0,06)$ menit, AUC $(11683,78 \pm 29,65)$ dan efisiensi disolusi $(97,56 \pm 0,25) \%$.
\end{abstract}

Kata kunci: atenolol; tablet orodispersible; campuran fisik; crospovidone; sodium starch glycolate

\begin{abstract}
Administration of conventional tablets of atenolol cause problems in terms of patient compliance in geriatric patients. This is due to physiological change in geriatric patients, especially difficulty in swallowing and tremors. The development of atenolol dispersible tablets can produce fast disintegration of tablets in the mouth, so that dissolution becomes faster. Selection of the type and composition of disintegrant is important in the formulation of orodispersible tablets. Combination of crospovidone and sodium starch glycolate as superdisintegran in orodispersible tablets can combine the wicking and swelling mechanism, thus accelerating the disintegration time of tablets. The objective of this study was to gain the effect of physical mixture of superdisintegrants (crospovidone-sodium starch glycolate) in $1: 1,1: 2$, and 1:3 ratio to the physicochemical characteristics of atenolol orodispersible tablets, which produce by the direct compression method. The results indicated that atenolol orodispersible tablets which using a physical mixture of superdisintegrants (crospovidone-sodium starch glycolate) in 1:1, 1:2, and 1:3 ratio met the requirements. Orodispersible tablets of atenolol which using a physical mixture of crospovidone-sodium starch glycolate in 1:1 ratio, showed the best results compare to the other formula in terms of $\% Q(96.92 \pm 0.01) \%, T_{85 \%}(1.76 \pm 0.06)$ minutes, AUC (11683.78 \pm 29.65$)$ and dissolution efficiency $(97.56 \pm 0.25) \%$.
\end{abstract}

Keywords: atenolol; orodispersible tablet; physical mixture; crospovidone; sodium starch glycolate 


\section{Pendahuluan}

Atenolol merupakan salah satu obat antihipertensi golongan beta blocker yang terrmasuk dalam daftar obat BPJS (Badan Penyelenggara Jaminan Sosial) kesehatan [1]. Karakteristik atenolol yang sukar larut dalam air mengakibatkan proses disolusi menjadi lambat sehingga mempengaruhi awal mula kerja obat dan bioavailabilitas atenolol dalam sirkulasi sistemik [2, 3]. Pada pasien dengan kondisi khusus terutama geriatri, penggunaan sediaan tablet konvensional atenolol menimbulkan permasalahan terkait fungsi fisik dan fisiologis pasien yaitu kesulitan dalam menelan tablet [3].

Pendekatan yang dapat dilakukan untuk meningkatkan disolusi atenolol adalah mempercepat waktu disintegrasi sediaan [4]. Sediaan tablet yang terdisintegrasi dengan cepat akan menghasilkan suspensi partikel obat yang halus sehingga dapat mempercepat mula disolusi obat $[4,5]$. Formulasi sediaan tablet orodispersible atenolol merupakan salah satu solusi untuk mempercepat mula disolusi atenolol dan meningkatkan kepatuhan pasien dalam terapi hipertensi [4].

Tablet orodispersible merupakan tablet yang dapat terdisintegrasi dalam waktu kurang dari atau sama dengan 30 detik saat diletakkan di atas lidah [6]. Tablet orodispersible dapat terdisintegrasi secara cepat di dalam rongga mulut, sehingga obat dapat diabsorbsi melalui rongga mulut, faring, dan esophagus saat saliva bergerak menuju saluran cerna [4, 7]. Waktu disintegrasi tablet yang cepat dapat menunjang terjadinya mula proses disolusi menjadi lebih cepat. Kondisi ini dapat menghasilkan onset aksi obat yang lebih cepat dan bioavailaibilitas obat yang lebih tinggi dibandingkan tablet konvensional [8].

Pemilihan superdisintegran yang optimal merupakan hal yang penting dalam formulasi sediaan tablet orodispersible. Hal ini disebabkan superdisintegran bersifat higroskopis sehingga apabila digunakan dalam kadar tinggi akan mempengaruhi kekerasan tablet, friabilitas tablet, dan adanya efek mouthfeel [9]. Salah satu jenis super- disintegran yang dapat digunakan dalam formulasi sediaan tablet orodispersibel adalah sodium starch glycolate. Sodium starch glycolate banyak digunakan karena memiliki kapasitas pengembangan (swelling) yang tinggi sehingga dapat mempercepat waktu hancur tablet [10]. Penggunaan sodium starch glycolate sebagai superdisintegran memiliki beberapa kekurangan antara lain menyerap kelembaban dalam jumlah yang cukup tinggi selama penyimpanan dan menggumpal bila disimpan dalam kondisi yang kelembabannya tidak terkendali. Selain itu, sodium starch glycolate memfasilitasi terbentuknya lapisan gel pada permukaan tablet saat proses disolusi sehingga menghalangi penetrasi air ke dalam tablet [11].

Berdasarkan kondisi tersebut, perlu dilakukan kombinasi sodium starch glycolate dengan superdisintegran lain. Salah satu superdisintegran yang dapat dikombinasikan dengan sodium starch glycolate adalah crospovidone. Crospovidone merupakan superdisintegran yang bekerja melalui kombinasi mekanisme kapilaritas (wicking) dan deformasi. Karakteristik crospovidone adalah memfasilitasi air masuk ke dalam struktur tablet, mampu menyebabkan tablet mengembang secara cepat dalam air tanpa membentuk gel pada permukaan tablet, dan memiliki kompresibilitas yang tinggi $[12,13]$. Penggunaan kombinasi superdisintegran sodium starch glycolate dan crospovidione diharapkan memiliki kemampuan disintegrasi cepat dan karakteristik fisik tablet yang baik saat penyimpanan $[14,15]$.

Pada penelitian ini dilakukan pembuatan sediaan tablet orodispersible atenolol dengan perbandingan campuran fisik sodium starch glycolate-crospovidone $1: 1 ; 1: 2$; dan 1:3 dengan metode cetak langsung. Perbedaan komposisi campuran fisik sodium starch glycolate dilakukan pengamatan pengaruhnya terhadap parameter pre kompresi (laju alir, sudut istirahat, indeks kompresibilitas, rasio Hausner, dan kandungan lembab) dan parameter post kompresi (organoleptis, penetapan kadar, keseragaman ukuran, kekerasan tablet, waktu hancur, waktu pembasahan, 
rasio penyerapan air, waktu dispersi tablet, dan disolusi atenolol). Analisis statistik dengan uji Anova satu arah (one way Anova) dilakukan terhadap parameter post kompresi meliputi waktu pembasahan, waktu dispersi tablet, rasio penyerapan air, dan parameter disolusi (AUC, efisiensi disolusi (ED), dan tetapan laju pelepasan (k).

\section{Metode}

\subsection{Bahan}

Bahan yang digunakan dalam penelitian ini adalah atenolol p.g (Refarmed Chemicals, Lugono Switzerland), crospovidone (Kollidon ${ }^{\circledR} \mathrm{CL}$ ) p.g (BASF South East Asia Pre-Ltd), sodium starch glycolate p.g (Yung Zip Chemical IND.Co.LTD), magnesium stearat p.g (Faci Asia Pacific PTE LTD), aspartam f.g (Ajinomoto Co. Inc.), aqua demineralisata (Laboratorium Kimia Kualitatif Universitas Surabaya), manitol DC p.g (Roduette Freses, Perancis), aerosil p.g (PT. Brataco), mint flavor f.g (KH Roberts), sodium dihidrogen fosfat p.a $\left(\mathrm{NaH}_{2} \mathrm{PO}_{4} \cdot 2 \mathrm{H}_{2} \mathrm{O}\right)$ p.a (Merck), disodium hidrogen fosfat p.a $\left(\mathrm{Na}_{2} \mathrm{HPO}_{4} \cdot 12 \mathrm{H}_{2} \mathrm{O}\right)$ p.a (Merck), natrium asetat trihidrat p.a. (Riedel), asam asetat glasial p.a (Merck), metanol pro HPLC (Mallinckrodt Chemicals), avicel PH 102 p.g (Mingtai Chemical Co. LTD), talk (PT. Brataco), kertas saring, whatmann no 41, dan perkamen.

\subsection{Alat}

Alat yang digunakan dalam penelitian ini meliputi timbangan analitik (Sartorius), tapping machine (Pharma Test Touch), tumbling mixer, mesin pencetak tablet (ERWEKA AR 402), moisture content analyzer, alat uji kekerasan tablet (monsanto hardness tester), alat uji friabilitas (ERWEKA), Spektrofotometer UV-Vis (SHIMADZU UV--1800), alat uji disintegrasi (Hanson Research), dan alat uji disolusi (Hanson Research).

\subsection{Metode pembuatan campuran fisik dan masa cetak}

\subsubsection{Pembuatan campuran fisik superdisintegran}

Pembuatan campuran fisik superdisintegran dilakukan dengan cara menimbang crospovidone dan sodium starch glycolate sesuai dengan perbandingan pada masing-masing formula (1:1, $1: 2$, dan 1:3), kemudian kedua bahan tersebut dicampur hingga homogen.

\subsubsection{Pembuatan masa cetak}

Bahan aktif (atenolol) dan eksipien ditimbang sesuai formula yang disusun (Tabel 1). Pembuatan massa cetak untuk masing-masing formula dilakukan sebagai berikut, yaitu pencampuran awal atenolol dan sebagian Aerosil ${ }^{\circledR}$ selama 3 menit, kemudian dilanjutkan pencampuran dengan sebagian Avicel PH $102^{\circledR}$ selama 5 menit. Aspartam, mint flavor, sisa Avicel PH $102^{\circledR}$, manitol DC dan campuran fisik superdisintegran (crospovidone dan sodium starch glycolate) 1:1 pada formula 1, 1:2 pada formula 2, 1:3 pada formula 3 ditambahkan kedalam campuran. Bahan-bahan tersebut dicampur dalam tumbling mixer hingga homogen selama 10 menit.

\subsection{Evaluasi pre kompresi}

Masa cetak yang telah dihasilkan kemudian dilakukan evaluasi pre kompresi meliputi kecepatan alir, sudut istirahat, indeks kompresibilitas, rasio Hausner, dan kandungan lembab.

\subsubsection{Kecepatan alir dan sudut istirahat}

Pemeriksaan kecepatan alir dan sudut istirahat dilakukan dengan menimbang 100 gram masa cetak. Masa cetak kemudian dituang ke dalam corong yang sudah terpasang pada statif dengan dengan jarak ujung pipa bagian bawah ke bidang datar adalah 10,0 \pm 0,2 $\mathrm{cm}$ dan dasar lubang corong ditutup. Tutup dasar lubang corong dibuka dan dilakukan pencatatan waktu yang diperlukan dari bahan mengalir sampai bahan dalam corong habis dengan menggunakan stopwatch sehingga kecepatan alir dapat dihitung. Tahap selanjutnya yaitu mengukur tinggi timbunan bahan dan jari-jari alas kerucut, kemudian menghitung sudut istirahat yang terbentuk [8].

\subsubsection{Indeks kompresibilitas}

Penentuan indeks kompresibilitas dilakukan dengan menentukan bobot jenis nyata dan bobot jenis mampat terlebih dahulu [14]. Hasil yang diperoleh kemudian digunakan untuk menghitung 
Tabel 1. Formula tablet orodispersibel atenolol dengan campuran fisik superdisintegran (crospovidonesodium starch glycolate)

\begin{tabular}{llll}
\hline \multirow{2}{*}{ Nama bahan } & \multicolumn{2}{l}{ Jumlah per tablet $(\mathbf{m g})$} & \\
\cline { 2 - 4 } & Formula $\mathbf{1}$ & Formula 2 & Formula 3 \\
\hline Atenolol & 25 & 25 & 25 \\
Campuran fisik superdisintegran & 30 & 30 & 30 \\
& CPV: 15 & CPV: 10 & CPV: 7,5 \\
Magnesium stearate & SSG: 15 & SSG: 20 & SSG: 22,5 \\
Aspartam & 4,5 & 4,5 & 4,5 \\
Mint flavor & 9 & 9 & 9 \\
Aerosil & 3 & 3 & 3 \\
Manitol DC & 1,5 & 1,5 & 1,5 \\
Avicel PH 102 & 44,82 & 44,82 & 44,82 \\
Talk & 179,28 & 179,28 & 179,28 \\
Total bobot per tablet $(\mathrm{mg})$ & 3 & 3 & 3 \\
\hline Keterangan & 300 & 300 & 300 \\
\hline
\end{tabular}

\section{Keterangan:}

Formula 1: tablet orodispersibel atenolol dengan campuran fisik crospovidone-sodium starch glycolate (1:1)

Formula 2: tablet orodispersibel atenolol dengan campuran fisik crospovidone-sodium starch glycolate $(1: 2)$

Formula 3: tablet orodispersibel atenolol dengan campuran fisik crospovidone-sodium starch glycolate (1:3)

indeks kompresibilitas masa cetak menggunakan persamaan indeks kompresibilitas (indeks Carr):

$$
\text { Indeks Kompresibilitas - } \frac{\rho \text { mampat }-\rho \text { nyata }}{\rho \text { mampat }} \times 100 \%
$$

\subsubsection{Rasio Hausner}

Rasio Hausner digunakan untuk memprediksi karakteristik aliran suatu masa cetak. Rasio Hausner dihitung melalui perbandingan antara bobot jenis mampat dan bobot jenis nyata suatu masa cetak [4].

\subsubsection{Kandungan lembab}

Massa cetak ditimbang secara seksama sebanyak $5 \mathrm{~g}$ dan permukaan massa cetak diratakan pada wadah. Letak lampu pemanas diatur sedemikian rupa sehingga berada di atas bahan. Pada saat proses pengeringan berlangsung, bobot massa cetak akan ditampilkan setiap 15 menit. Proses pengeringan dikatakan sempurna apabila setelah interval $3 \times 15$ menit tidak terjadi perubahan bobot massa cetak. Moisture content dapat dihitung dengan rumus, $\% \mathrm{MC}=\frac{\mathrm{W}-\mathrm{Wo}}{\mathrm{Wo}} \times 100 \%$
Dimana W adalah bobot massa cetak basah dan Wo adalah bobot massa cetak kering [16].

\subsection{Pencetakan tablet orodispersibel atenolol}

Massa cetak dicampur dengan magnesium stearat, talk dan sisa aerosil selama 3 menit dengan tumbling mixer hingga homogen. Campuran serbuk kemudian dikompresi menjadi tablet dengan menggunakan mesin pencetak tablet ERWEKA ${ }^{\circledR}$ AR 402 dengan bobot per tablet $300 \mathrm{mg}$. Diameter punch $11 \mathrm{~mm}$, permukaan punch bulat biconvex, dan gaya kompresi 2 ton. Evaluasi postkompresi dilakukan setelah proses kompresi tablet.

\subsection{Evaluasi post kompresi}

Tablet orodispersible atenolol yang dihasilkan setelah proses kompresi tablet kemudian dilakukan evaluasi post kompresi meliputi organoleptis, penetapan kadar atenolol, kekerasan, waktu pembasahan, rasio penyerapan air, waktu disintegrasi, waktu disperse tablet, uji friabilitas, dan uji disolusi. 


\subsubsection{Organoleptis}

Evaluasi organoleptis dilakukan dengan cara mengamati penampilan fisik setiap tablet masing-masing formula, meliputi bau, warna, rasa, dan bentuk sediaan tablet orodispersible atenolol yang sudah dicetak $[11,18]$.

\subsubsection{Penetapan kadar atenolol}

Dilakukan pengambilan masing-masing 20 tablet setiap formula secara acak. Masing-masing tablet digerus. Campuran atenolol yang setara dengan $25 \mathrm{mg}$ ditimbang dan dilarutkan dengan $10 \mathrm{ml}$ metanol, kemudian ditambahkan dapar asetat pH 4,6 hingga $100 \mathrm{ml}$ di dalam labu ukur. Dari larutan tersebut dipipet sebanyak $10 \mathrm{ml}$, kemudian ditambahkan dapar asetat hingga $25 \mathrm{ml}$ dalam labu ukur. Larutan tersebut selanjutnya difiltrasi dengan kertas whatmann no. 41. Larutan yang telah disaring, dilihat absorbansinya pada spektrofotometer UV-VIS pada panjang gelombang $274 \mathrm{~nm}$ dengan blanko dapar asetat $\mathrm{pH}$ 4,6 [8].

\subsubsection{Kekerasan tablet}

Pengujian kekerasan tablet dilakukan dengan mengambil sampel sebanyak 10 tablet dari masing-masing formula [4]. Pengujian kekerasan tablet dilakukan dengan Monsanto hardness tester.

\subsubsection{Waktu pembahasan dan rasio penyerapan air}

Waktu pembasahan dan rasio penyerapan air dilakukan dengan meletakkan tablet dari masingmasing formula ke dalam cawan petri yang sudah berisi $6 \mathrm{ml}$ larutan pewarna dalam air [4, 8]. Waktu yang dibutuhkan cairan untuk mencapai permukaan atas tablet adalah waktu pembasahan dan massa air yang mampu diserap tablet merupakan rasio penyerapan air.

\subsubsection{Waktu disintegrasi}

Sebanyak 6 tablet setiap formula ditempatkan pada masing-masing tabung dengan air $900 \mathrm{ml}$ pada suhu $37 \pm 0,5^{\circ} \mathrm{C}$. Bersamaan dengan dimulainya alat uji, stopwatch dinyalakan. Waktu yang diperlukan agar tablet hancur atau massa intinya tidak teraba merupakan waktu hancur tablet tersebut $[4,6]$.

\subsubsection{Waktu dispersi secara in vitro}

Masing-masing tablet dari ketiga formula di- letakkan di dalam beaker yang berisi $6 \mathrm{ml}$ dapar fosfat $\mathrm{pH} 6,8$ dengan suhu $37 \pm 0,5^{\circ} \mathrm{C}$. Waktu yang diperlukan oleh tablet tersebut untuk hancur dicatat sebagai waktu dispersi secara in vitro $[4,8]$.

\subsubsection{Uji friabilitas/kerapuhan tablet}

Sampel tablet sebanyak 6,5 gram dimasukkan ke dalam alat uji friabilitas tablet. Alat uji dioperasikan dengan kecepatan 25 rpm selama 4 menit. Bobot seluruh tablet kemudian ditimbang kembali dan dihitung selisih antara bobot tablet sebelum dan setelah uji $[4,16]$. Persentase friabilitas tablet dihitung dengan rumus:

$$
\% \text { friabilitas - } \frac{\text { Bobot awal - Bobot akhir }}{\text { Bobot awal }} \times 100 \%
$$

\subsubsection{Uji disolusi}

Uji disolusi tablet orodispersibel atenolol dilakukan dengan menggunakan alat uji disolusi tipe 2 dengan kecepatan $50 \mathrm{rpm}$. Tahap awal yang dilakukan adalah memasukkan 6 tablet tiap formula ke dalam alat uji disolusi. Kemudian mengambil cuplikan sebanyak $10 \mathrm{ml}$ tiap satuan waktu, yaitu $0,1,2,3,4,5,10,15,20,25,30,45,60$, 75, 90, 105, dan 120 menit. Kemudian, mengembalikan $10 \mathrm{ml}$ dapar asetat ke dalam alat. Tahap selanjutnya adalah penetapan kadar atenolol tiap cuplikan menggunakan spektrofotometer pada panjang gelombang $274 \mathrm{~nm}$. Berdasarkan hasil yang diperoleh kemudian ditentukan parameter disolusi (\%Q, tQ\%, luas area di bawah kurva disolusi (AUC), dan efisiensi disolusi) dan profil disolusi [8].

\subsection{Analisis data}

Hasil pemeriksaan karakteristik tablet orodispersibel atenolol dengan konsentrasi sodium starch glycolate 0\% (kontrol), 10\% (formula 2), dan 20\% (formula 3) dilakukan analisis statistik dengan menggunakan uji Anova satu arah (one way Anova) dengan taraf kepercayaan 95\% $(\alpha=0,05)$. Analisis statistik dengan uji Anova satu arah dilakukan terhadap parameter post kompresi meliputi waktu pembasahan, waktu disperse tablet, rasio penyerapan air, dan parameter disolusi (AUC, efisiensi disolusi (ED), dan tetapan laju pelepasan $(\mathrm{k})$. 


\section{Hasil dan pembahasan}

\subsection{Evaluasi pre kompresi}

Evaluasi pre-kompresi dilakukan pada massa cetak yang sudah terbentuk. Evaluasi pre-kompresi meliputi pemeriksaan laju alir, sudut istirahat, bobot jenis nyata, bobot jenis mampat, indeks kompresibilitas, rasio Hausner, kandungan lembab [13, 14]. Hasil evaluasi pre kompresi masa cetak tablet orodispersible atenolol dapat dilihat pada Tabel 2 .

Hasil evaluasi pre-kompresi menunjukkan massa cetak tablet orodispersible atenolol memenuhi spesifikasi laju alir dan sudut istirahat, tetapi tidak memenuhi spesifikasi rasio Hausner, indeks kompresibilitas, dan kandungan lembab. Rasio Hausner dan indeks kompresibilitas yang kurang baik disebabkan karena massa cetak mengandung partikel fines dalam jumlah yang besar [15]. Karakteristik kompresibilitas suatu masa cetak dapat ditingkatkan dengan cara memperbaiki ukuran dan distribusi ukuran partikel [15]. Distribusi ukuran partikel dapat diperbaiki dengan cara mengurangi proporsi partikel fines dan meningkatkan partikel coarse dengan metode granulasi [15].

Kandungan lembab yang tinggi pada masa cetak disebabkan karena adanya eksipien yang bersifat higroskopis dalam formula. Komponen superdisintegran (crospovidone dan sodium starch glycolate) dan Avicel PH $102^{\circledR}$ (mikrokristalin selulosa) memiliki afinitas yang tinggi terhadap air sehingga massa cetak menyerap lembab dari udara [15]. Berdasarkan fakta tersebut, diperlukan pengendalian terhadap kelembaban ruangan selama proses pembuatan tablet orodispersible atenolol.

\subsection{Evaluasi post- kompresi}

Evaluasi post-kompresi dilakukan untuk menjamin mutu sediaan tablet orodispersible atenolol agar sesuai dengan persyaratan dan spesifikasi. Evaluasi post kompresi tablet orodispersible atenolol meliputi pemeriksaan organoleptis, penetapan kadar atenolol, kekerasan tablet, waktu pembasahan, rasio penyerapan air, waktu disintegrasi, waktu disperse tablet, friabilitas, dan uji disolusi. Hasil evaluasi post-kompresi dapat dilihat pada Tabel 3. Hasil evaluasi post-kompresi sediaan tablet orodispersible atenolol yang dihasilkan (formula 1, formula 2, dan formula 3) memenuhi persyaratan mutu $[6,17]$.

Analisis statistik dengan uji Anova satu arah dilakukan untuk menganalisis ada atau tidaknya perbedaan signifikan ketiga formula tablet orodispersible atenolol dari parameter waktu pembasahan, rasio penyerapan air, waktu dispersi in vitro, dan parameter disolusi (AUC, ED, dan k). Pemeriksaan waktu pembasahan dilakukan untuk menganalisis kecepatan penyerapan air tablet orodispersible atenolol. Hasil analisis statistik dengan uji Anova satu arah pada parameter waktu pembasahan tablet menunjukkan terdapat

Tabel 2. Hasil evaluasi pre kompresi masa cetak tablet orodispersibel atenolol dengan campuran fisik superdisintegran (crospovidone-sodium starch glycolate)

\begin{tabular}{lllll}
\hline Parameter & Formula 1 & Formula 2 & Formula 3 & Spesifikasi \\
\hline Kecepatan alir (g/detik) & $6,83 \pm 0,27$ & $8,33 \pm 0,00$ & $5,56 \pm 0,00$ & $>4,00$ \\
Sudut istirahat $\left(^{\circ}\right.$ ) & $30,78 \pm 1,81$ & $30,36 \pm 1,08$ & $28,07 \pm 1,88$ & $25-30$ \\
Indeks kompresibilitas (\%) & $25,98 \pm 0,32$ & $26,38 \pm 0,52$ & $26,01 \pm 0,42$ & $5-21$ \\
Rasio hausner & $1,35 \pm 0,006$ & $1,36 \pm 0,010$ & $1,35 \pm 0,008$ & \\
Kandungan lembab (\%) & $5,61 \pm 0,06$ & $5,42 \pm 0,05$ & $5,53 \pm 0,12$ & $3-5$ \\
\hline
\end{tabular}

\section{Keterangan:}

Formula 1: tablet orodispersibel atenolol dengan campuran fisik crospovidone-sodium starch glycolate (1:1)

Formula 2: tablet orodispersibel atenolol dengan campuran fisik crospovidone-sodium starch glycolate (1:2)

Formula 3: tablet orodispersibel atenolol dengan campuran fisik crospovidone-sodium starch glycolate (1:3) 
Tabel 3. Hasil evaluasi post kompresi tablet orodispersible atenolol dengan campuran fisik superdisintegran (crospovidone-sodium starch glycolate)

\begin{tabular}{lllll}
\hline Parameter & Formula 1 & Formula 2 & Formula 3 & Spesifikasi \\
\hline Organoleptis & bentuk bulat, & bentuk bulat, & bentuk bulat, & bentuk bulat, \\
& $\begin{array}{l}\text { warna putih, } \\
\text { rasa manis, bau } \\
\text { mint }\end{array}$ & $\begin{array}{l}\text { wasna putih, } \\
\text { rasanis, bau }\end{array}$ & $\begin{array}{l}\text { warna putih, } \\
\text { rasa manis, bau } \\
\text { mint }\end{array}$ & $\begin{array}{l}\text { rasa manis, bau } \\
\text { mint }\end{array}$ \\
& $94,25 \pm 0,46$ & $97,29 \pm 4,64$ & $97,51 \pm 1,35$ & $90 \%-110$ \\
Kadar atenolol (\%) & $3,45 \pm 0,44$ & $3,45 \pm 0,44$ & $3,10 \pm 0,21$ & $2-4$ \\
Kekerasan (Kp) & $6,33 \pm 0,58$ & $9,00 \pm 0,00$ & $9,00 \pm 1,00$ & - \\
Waktu pembasahan (detik) & $228,05 \pm 11,54$ & $255,57 \pm 21,53$ & $263,23 \pm 14,77$ & - \\
Rasio penyerapan air (\%) & $8,00 \pm 0,00$ & $7,00 \pm 0,00$ & $8,00 \pm 0,00$ & - \\
Waktu disintegrasi (detik) & $79,00 \pm 16,52$ & $66,67 \pm 11,37$ & $63,67 \pm 35,44$ & - \\
Waktu dispersi in vitro (detik) & $0,20 \pm 0,09$ & $0,35 \pm 0,08$ & $0,30 \pm 0,15$ & $<1,0$ \\
Friabilitas (\%) & $96,92 \pm 0,01$ & $93,42 \pm 0,02$ & $91,49 \pm 0,02$ & 85 \\
\%Q 30 menit & $1,76 \pm 0,06$ & $2,47 \pm 0,00$ & $3,23 \pm 0,27$ & 30 \\
T85\% (menit) & & & & \\
\hline
\end{tabular}

Keterangan:

Formula 1: tablet orodispersibel atenolol dengan campuran fisik crospovidone-sodium starch glycolate (1:1)

Formula 2: tablet orodispersibel atenolol dengan campuran fisik crospovidone-sodium starch glycolate (1:2)

Formula 3: tablet orodispersibel atenolol dengan campuran fisik crospovidone-sodium starch glycolate (1:3)

perbedaan bermakna antara formula 1 dengan 2 , dan antara formula 1 dengan formula $3(\mathrm{p}<0,05)$. Peningkatan proporsi sodium starch glycolate dalam formula menyebabkan waktu pembasahan tablet menjadi lebih lama. Kondisi ini disebabkan sodium starch glycolate pada formula 2 dan formula 3 membentuk gel pada permukaan tablet, sehingga pori matriks tablet tertutup. Kondisi ini menyebabkan waktu pembasahan tablet menjadi lebih lama [15]. Rasio penyerapan air menunjukkan kapasitas air yang dapat diserap dalam sediaan tablet orodispersible atenolol. Hasil analisis statistik menunjukkan tidak ada perbedaan bermakna antar formula 1, 2, dan 3 dari segi rasio penyerapan air $(p>0,05)$.

Sediaan tablet orodispersible diformulasi untuk diletakkan dalam mulut dan terdispersi atau terlarut dalam saliva, sehingga tidak memerlukan air yang banyak untuk dapat ditelan [12]. Dapar fosfat $\mathrm{pH}$ 6,8 dengan volume $6 \mathrm{ml}$ merupakan media yang sesuai untuk menggambarkan cairan saliva dalam mulut secara in vitro $[13,14]$. Hasil analisis menunjukkan tidak terdapat perbedaan bermakna waktu dispersi in vitro antara formula
1, 2, dan $3(p>0,05)$. Sodium starch glycolate akan meningkatkan kemampuan tablet untuk menarik air. Air yang masuk ke dalam tablet menyebabkan proses pengembangan, sehingga waktu dispersi tablet semakin cepat [15].

Uji disolusi bertujuan untuk menganalis pelepasan bahan aktif dari bentuk sediaan tablet yang dapat digunakan sebagai data untuk menggambarkan bioavailabilitas bahan aktif secara invitro [16]. Profil disolusi tablet orodispersibel atenolol formula 1, 2, dan 3 dapat dilihat pada Gambar 1.

Persyaratan mutu disolusi untuk tablet atenolol adalah jumlah bahan aktif yang terlarut dari setiap unit pada waktu 30 menit tidak kurang dari 85\% (\%Q) [17]. Hasil parameter \%Q 30 menit dan T85\% tablet orodispersibel atenolol formula 1, 2, dan 3 pada seluruh replikasi (6 replikasi tiap formula) memenuhi persyaratan mutu [17].

Hasil analisis statistik parameter AUC, ED, dan $\mathrm{k}$ dengan menggunakan uji Anova satu arah menunjukkan adanya perbedaan bermakna antar formula 1, 2, dan 3 ( $p>0,05)$. Perbedaan parameter AUC, ED, dan $\mathrm{k}$ yang signifikan antar 


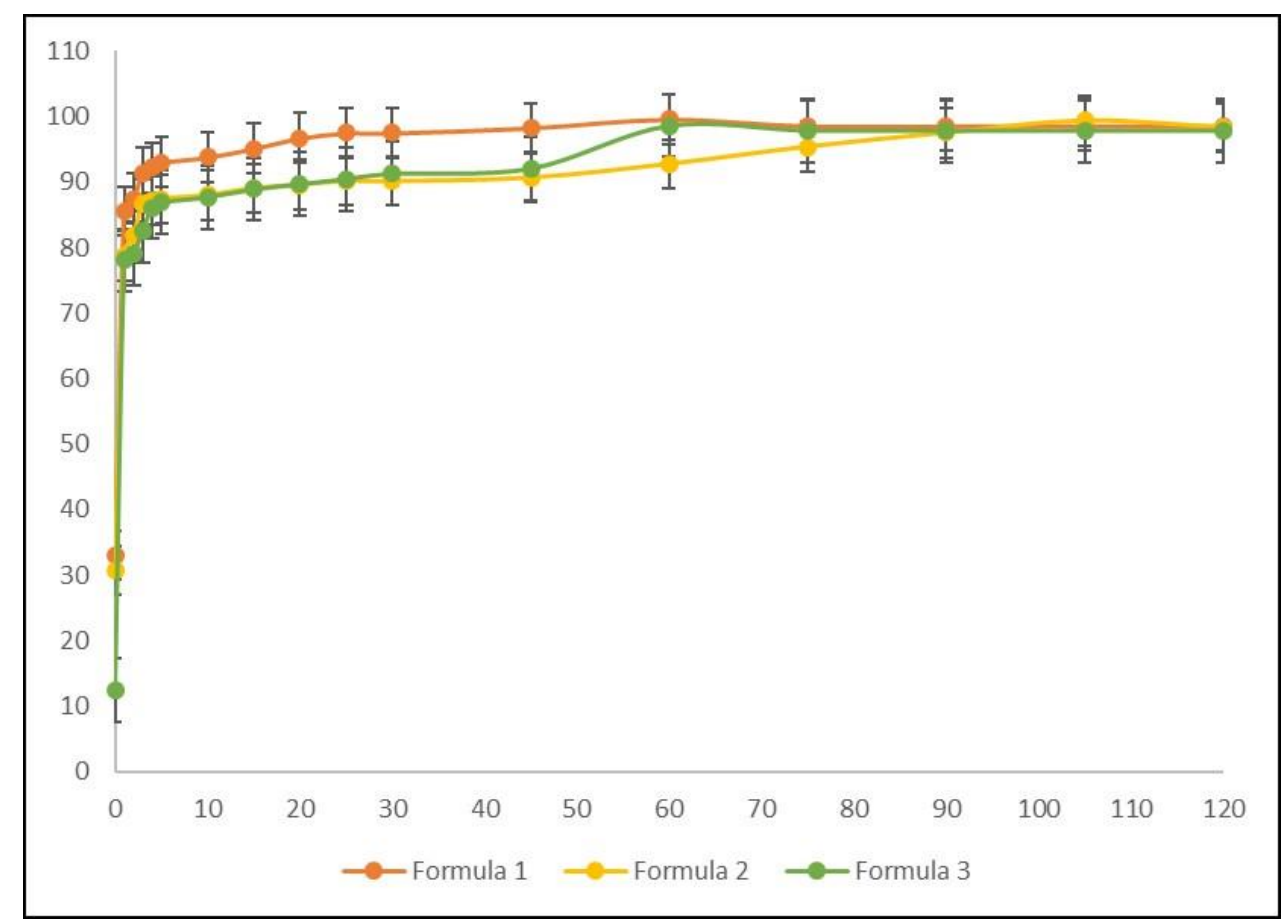

Gambar 1. Profil disolusi tablet orodispersibel atenolol formula 1, formula 2, dan formula 3

formula disebabkan karena perbedaan konsentrasi sodium starch glycolate. Pada formula 1 (perbandingan crospovidone dan sodium starch glycolate 1:1), jumlah atenolol terlarut dari tablet orodispersible lebih besar dibandingkan formula 2 (perbandingan crospovidone dan sodium starch glycolate 1:2) dan formula 3 (perbandingan crospovidone dan sodium starch glycolate 1:3). Hal ini disebabkan karena pada formula 2 dan 3, konsentrasi sodium starch glycolate lebih tinggi dibandingkan formula 1, sehingga gel terbentuk lebih cepat dan jumlah gel lebih besar dibandingkan formula 1. Gel yang terbentuk dapat menghambat pelepasan atenolol dari bentuk sediaan. Pelepasan atenolol yang terhambat akan mengurangi jumlah atenolol yang dapat terlarut dalam media disolusi [15]. Berdasarkan hasil tersebut diketahui bahwa nilai AUC dan efisiensi disolusi formula $1(97,56 \%)$ lebih besar 1,05 kali dibandingkan formula $2(93,05 \%)$ dan 1,04 kali dibandingkan formula 3 .

\section{Kesimpulan}

Perbedaan komposisi campuran fisik superdisintegran (crospovidone- sodium starch glyco- late) $1: 1,1: 2$, dan $1: 3$ berpengaruh terhadap waktu pembasahan tablet orodispersible atenolol yan dibuat dengan metode cetak langsung. Sediaan tablet orodispersible atenolol dengan komposisi campuran fisik superdisintegran (crospovidonesodium starch glycolate) 1:1, 1:2, dan 1:3 yang dibuat dengan metode cetak langsung memenuhi persyaratan mutu. Sediaan tablet orodispersible atenolol dengan komposisi campuran fisik superdisintegran (crospovidone-sodium starch glycolate) 1:1 merupakan formula yang optimal. Hal ini disebabkan formula tersebut menghasilkan parameter disolusi (AUC, ED, dan k) yang lebih tinggi dibandingkan formula dengan komposisi campuran fisik superdisintegran (crospovidonesodium starch glycolate) 1:2 dan 1:3.

\section{Ucapan Terima Kasih}

Ucapan terimakasih disampaikan kepada Kemenristek DIKTI dan Lembaga Penelitian dan Pengabdian Masyarakat (LPPM) Universitas Surabaya atas pendanaan penelitian ini dalam skema penelitian produk terapan tahun 2017 dengan nomor kontrak penelitian 24/SP-Lit/LPPM-01/ Dikti/FF/V/2017. 


\section{Daftar Pustaka}

1. Kementerian Kesehatan Republik Indonesia. Formularium nasional. Jakarta: Kementerian Kesehatan Republik Indonesia; 2015.

2. Sweetman. Martindale the complete drug reference $36^{\text {th }}$ edition. London: Pharmaceutical Press; 2009.

3. Nagar P, Singh K, Chauhan I, Yasir M, Khan A, Sharma R, Gupta N. Orally Disintegrating Tablets: Formulation, preparation, techniques, and evaluation. Journal of Applied Pharmaceutical Science. 2011;2:35-45.

4. Kumare MM, Marathe RP, Kawade RM, Ghante MH, Shendarkar RR. Design of Fast Dissolving Tablet of Atenolol Using Novel Co-Processed Superdisintegrant. Asian Journal of Pharmaceutical and Clinical Research. 2013;6(3):81-5.

5. Sinko PJ. Martin Farmasi Fisika dan Ilmu Farmasetika. Jakarta: Penerbit Buku Kedokteran EGC; 2006.

6. US Department of Health and Human Services Food and Drug Administration Center for Drug Evaluation and Research. Guidance for industry: orally disintegrating tablets. New Hampsire eve: Division of drug information food and drug administration; 2008.

7. Fu Y, Yang S, Jeong S, Kimuru S, Park K. Orally fast disintegrating tablets: developments, technologies, taste-masking and clinical studies. Critical Review in Therapeutic Drug Carrier Systems. 2004;21(6): 433-75.

8. Chandrasekhar P, Shahid M, Niranjan B. Formulation and evaluation of oral dispersible tablets of antihypertensive drug atenolol. International
Journal of Pharmacy. 2013;3(2): 79-84.

9. Camarco W and Druffner A. Selecting superdisintegrant for orally disintegrating tablet formulation. Pharmaceutical Technology. 2006;5:1-5.

10. Ramani RG, Road S, Address C. Novel co-processed superdisintegrants in the design of fast dissolving tablets. International Journal of Pharma and Bio Sciences. 2010;1(1):1-12.

11. Racmawati AN, Wahyono, Sulaiman TN. Optimization formula dispersible tablets of guajava leaf extract (Psidium guajava L.) with combination disintegrants of croscarmellose sodium and sodium starch glycolate. Traditional Medicine Journal. 2015;20(1):43-50.

12. Hahm HA, Augsburger LL. Orally disintegrating tablets and related tablet formulations: In pharmaceutical dosage forms tablets. New York: Informa Healthcare; 2008.

13. Priyanka S, Vandana S. A review article on: superdisintegrants. International journal of drug research and technology. 2013;3(4):76-87.

14. Karthikeyan M, Karthikraja M, Rooswelt C, Lokesh D, Venkateswariu Y, Naresh Y. Formulation and evaluation of oral dispersible tablets of atenolol using superdisintegran. International journal of biological. 2013;3(1):663-71.

15. Mahendrakumar P, Liew CV, Heng PW. Review of disintegrants and disintegration phenomena.Journal of pharmaceutical scinces. 2016;105:2545-55.

16. Aulton M, Summers M. Tablet and compaction in : Pharmaceutics the science of dosage form design. Philadelphia:Churchill Livingstone; 2013

17. Departemen Kesehatan Republik Indonesia. Farmakope Indonesia Edisi V. Jakarta:Departemen Kesehatan Republik Indonesia; 2014. 